\title{
Pemantauan gizi dengan SMS reminder efektif meningkatkan kepatuhan diet pasien hemodialisis
}

Nutritional monitoring with SMS reminder is effective to increase the dietary compliance of hemodialysis patients

\author{
Fery Lusviana Widiany, Yuni Afriani
}

Program Studi Gizi, Fakultas Ilmu Kesehatan, Universitas Respati Yogyakarta

\begin{abstract}
Background: Patients with routine hemodialysis are at risk of malnutrition, inadequate intake of protein, hypoalbuminemia, gastrointestinal disorders. One of the factors affecting dietary compliance is knowledge so that the education and nutrition monitoring on an ongoing basis is necessary. Objective: To determine the effectiveness of nutrition monitoring with SMS reminders on dietary compliance of hemodialysis patients. Methods: This was a quasi-experimental study that involved 30 regular hemodialysis patients, divided into two groups. The inclusion criteria were aged $>18$ years, willing to become respondent and following the procedure, have a handphone, able to read and write. Patients with anasarca edema and complications of malignancy disease were excluded. The independent variable is nutritional monitoring with SMS reminders, while the dependent variable is dietary compliance. Data were statistically analyzed using the Chi-Square test and multiple logistic regression test. Results: Statistical analysis showed that nutritional monitoring with SMS reminder effectively influences the compliance on the consumption of energy $(p=0.011, R R=2.750)$, fluid ( $p=0.014, R R=2.000$ ), and potassium ( $p=0.011, R R=2.750$ ). The compliance on the consumption of fluid is the most dominant factor affected by nutrition monitoring with SMS reminders given ( $B=3.676, p=0.02)$. Conclusions: Nutritional monitoring with SMS reminders is effective to increase the dietary compliance of hemodialysis patients.
\end{abstract}

KEYWORDS: dietary compliance; hemodialysis patients; SMS reminder

\begin{abstract}
ABSTRAK
Latar belakang: Pasien yang menjalani hemodialisis rutin berisiko mengalami malnutrisi, asupan protein inadekuat, hipoalbumin, dan gangguan gastrointestinal. Salah satu faktor yang memengaruhi kepatuhan diet adalah pengetahuan sehingga edukasi dan pemantauan gizi sangat diperlukan. Tujuan: Penelitian ini bertujuan untuk mengetahui efektivitas pemantauan gizi dengan $S M S$ reminder terhadap kepatuhan diet pasien hemodialisis. Metode: Penelitian kuasi eksperimental dengan melibatkan 30 orang pasien hemodialisis yang terbagi dalam dua kelompok. Kriteria inklusi yaitu berusia lebih dari 18 tahun, bersedia menjadi responden dan mengikuti prosedur penelitian, memiliki dan mampu mengoperasikan telepon genggam, dapat membaca dan menulis. Pasien dengan oedema anasarka dan komplikasi keganasan penyakit dieksklusi. Variabel independen yaitu pemantauan gizi dengan SMS reminder sedangkan variabel dependen adalah kepatuhan diet. Analisis data dengan uji Chi-Square dan uji regresi logistik ganda. Hasil: Analisis menunjukkan bahwa pemantauan gizi dengan SMS reminder efektif memengaruhi kepatuhan responden dalam mengonsumsi energi $(p=0,011 ; R R=2,750)$, cairan $(p=0,014 ; R R=2,000)$, dan kalium $(p=0,011 ; R R=2,750)$. Kepatuhan dalam mengonsumsi cairan merupakan faktor yang paling dominan dipengaruhi oleh pemantauan gizi dengan SMS reminder yang diberikan $(\mathrm{B}=3,676 ; \mathrm{p}=0,02)$. Simpulan: Pemantauan gizi dengan SMS reminder efektif meningkatkan kepatuhan diet pasien hemodialisis.
\end{abstract}

KATA KUNCI: kepatuhan diet; pasien hemodialisis; SMS reminder

Korespondensi: Fery Lusviana Widiany, Program Studi Gizi, Fakultas Ilmu Kesehatan Universitas Respati Yogyakarta, Jl. Raya Tajem KM 1,5 Maguwoharjo, Depok, Sleman, Yogyakarta, Indonesia, e-mail: fer_luzz_wee@yahoo.com 


\section{PENDAHULUAN}

Prevalensi penyakit ginjal kronik di provinsi Daerah Istimewa Yogyakarta (DIY) dan Jawa Tengah masingmasing sebesar $0,3 \%$, lebih tinggi $0,1 \%$ dibandingkan dengan prevalensi rata-rata seluruh Indonesia yang hanya $0,2 \%$ (1). Penyakit ginjal kronik adalah keadaan fungsi ginjal yang mengalami penurunan cukup berat dan terjadi perlahan-lahan (menahun) yang disebabkan oleh berbagai penyakit ginjal, bersifat progresif, dan umumnya tidak dapat pulih. Kondisi ini menyebabkan ginjal gagal untuk mempertahankan metabolisme serta keseimbangan cairan dan elektrolit (2) sehingga diperlukan terapi pengganti berupa hemodialisis. Pasien yang menjalani hemodialisis rutin akan mengalami malnutrisi, asupan protein yang tidak adekuat, rendahnya kadar albumin dalam darah, gangguan gastrointestinal seperti rasa mual, muntah, dan menurunnya nafsu makan (3). Oleh karena itu, kepatuhan diet sangat diperlukan untuk mengatasi masalah malnutrisi pada pasien hemodialisis.

Sebagian besar pasien merasa bosan dalam mematuhi diet hemodialisis yang diberikan pada saat konsultasi gizi sehingga pasien pun tidak mengatur diet dengan baik. Terdapat pula pasien yang dengan sadar masih mengonsumsi makanan bernatrium tinggi seperti makanan berpengawet, ikan asin, telur asin, serta membeli makanan yang diolah dengan penyedap rasa (monosodium glutamate / MSG) (4).

Salah satu faktor yang mempengaruhi kepatuhan dalam melaksanakan program diet adalah pengetahuan (5). Edukasi dan komunikasi oleh seorang tenaga kesehatan dapat memberikan informasi yang lengkap guna meningkatkan pengetahuan pasien dalam setiap instruksi yang diberikan kepadanya sehingga dapat meningkatkan kepatuhan pasien dalam menjalankan terapi. Selain edukasi gizi, diperlukan juga usaha pemantauan gizi untuk mengetahui perkembangan kondisi pasien hemodialisis. Pemantauan gizi dilakukan karena pasien hemodialisis merupakan pasien rawat jalan sehingga terkadang kesulitan untuk mengingat diet yang harus dilakukan. Pemantauan gizi salah satunya dapat dilakukan dengan sistem pengingat melalui short message service atau SMS (SMS reminder). Dengan demikian, tujuan penelitian ini adalah untuk mengkaji lebih lanjut mengenai efektivitas pemantauan gizi dengan SMS reminder terhadap kepatuhan diet pasien hemodialisis.

\section{BAHAN DAN METODE}

Penelitian berjenis kuasi eksperimen dengan rancangan pre-post with one group control design yang dilaksanakan di Unit Hemodialisis RSUP Dr. Soeradji Tirtonegoro Klaten pada bulan April - Agustus 2016. Penelitian ini melibatkan 30 orang responden yang terbagi menjadi kelompok perlakuan dan kelompok kontrol (masing-masing 15 orang). Perhitungan sampel menggunakan rumus besar sampel (6) dengan tingkat kesalahan $(\alpha)$ sebesar 0,05 ; proporsi efek kelompok perlakuan $\left(\mathrm{P}_{1}\right)$ ditentukan 50\%; proporsi efek kelompok kontrol $\left(\mathrm{P}_{2}\right)$ ditentukan 87,1\% (7); kesalahan tipe II $(\beta)$ ditentukan 0,20 ; dan kekuatan pengaruh/ power $\left(Z_{1-} \beta\right)$ ditentukan $80 \%$. Pengambilan sampel menggunakan teknik purposive sampling yaitu dengan cara mengambil sampel pasien hemodialisis pada 3 shift (pagi, siang, dan sore) hari senin hingga sabtu yang memenuhi kriteria inklusi eksklusi penelitian. Kriteria inklusi penelitian yaitu usia lebih dari 18 tahun, bersedia menjadi responden dan mengikuti prosedur penelitian, memiliki dan mampu mengoperasikan telepon genggam, serta dapat membaca dan menulis. Pasien dengan oedema anasarka dan komplikasi keganasan penyakit dieksklusi.

Responden kelompok pelakuan diberikan perlakuan berupa pengiriman SMS 1 kali sehari secara berkesinambungan selama 1 bulan dengan materi yang berbeda setiap harinya (30 SMS per responden). SMS reminder tersebut dikirimkan pada pagi hari (sekitar pukul 08.00 WIB). SMS tersebut berisi materi singkat mengenai diet hemodialisis. Pada masing-masing akhir SMS selalu dicantumkan slogan "Sehat bugar dengan penerapan diet hemodialisis yang tepat" untuk meningkatkan motivasi responden dalam menerapkan diet hemodialisis yang diberikan. Sementara kelompok kontrol hanya memperoleh konsultasi gizi dari ahli gizi rumah sakit sesuai prosedur standar yang berlaku di rumah sakit tersebut. Konsultasi gizi dari ahli gizi rumah sakit sesuai prosedur standar di rumah sakit tersebut juga diberikan kepada responden kelompok perlakuan.

Kepatuhan diet didefinisikan sebagai kepatuhan responden dalam mengonsumsi zat gizi makro dan 
mikro sesuai diet yang dianjurkan, terlihat dari kategori persen asupan energi, cairan, dan kalium. Data asupan diperoleh dengan metode food record, yaitu responden mencatat sendiri semua makanan dan minuman yang dikonsumsi setiap hari dengan pendampingan keluarga selama 1 bulan sesuai masa pemberian intervensi kepada responden. Data asupan tersebut kemudian diolah menggunakan Nutrisurvey untuk menganalisis nilai gizi asupan responden. Nilai gizi asupan responden tersebut dibandingkan dengan kebutuhan responden yang dihitung per individu. Kebutuhan energi pasien hemodialisis yang digunakan sebagai pembanding adalah $35 \mathrm{kcal} / \mathrm{kg}$ berat badan/hari, cairan dengan kebutuhan balance (volume urin 24 jam ditambah $500-750 \mathrm{cc}$ ), dan kebutuhan kalium $40 \mathrm{mg} / \mathrm{kg}$ berat badan/hari. Persentase asupan energi, cairan, dan kalium kemudian dikategorikan menurut World Health Organization (WHO) (2005), yaitu asupan baik jika terpenuhi $80-110 \%$ kebutuhan dan asupan tidak baik jika kurang dari $80 \%$ atau lebih dari $110 \%$ kebutuhan. Responden dikatakan patuh jika rerata asupan zat gizi tetap baik atau mengalami perubahan dari tidak baik menjadi baik sebelum dan setelah intervensi diberikan. Sementara kategori tidak patuh jika rerata asupan zat gizi tetap tidak baik, atau mengalami perubahan dari baik menjadi tidak baik sebelum dan setelah intervensi diberikan.

Semua data dianalisis univariat untuk mengetahui distribusi frekuensi setiap variabel, analisis bivariat dengan uji Chi-Square untuk mengetahui hubungan variabel independen dan dependen, dilanjutkan analisis multivariat dengan uji regresi logistik ganda untuk melihat variabel yang paling dominan dipengaruhi oleh variabel independen. Penelitian ini telah memperoleh kelaikan etik (ethical clearance) dari Komisi Etik Fakultas Ilmu Kesehatan Universitas Respati Yogyakarta No. 198.4/FIKES/PL/IV/2016.

\section{HASIL}

Karakteristik responden penelitian ini ditampilkan pada Tabel 1 sedangkan distribusi responden berdasarkan asupan energi, cairan, kalium pre dan post-intervensi ditampilkan pada Tabel 2.

Kepatuhan diet responden dalam penelitian diketahui dari perubahan asupan zat gizi sebelum dan setelah diberikan intervensi yang ditampilkan pada

\section{Gambar 1.}

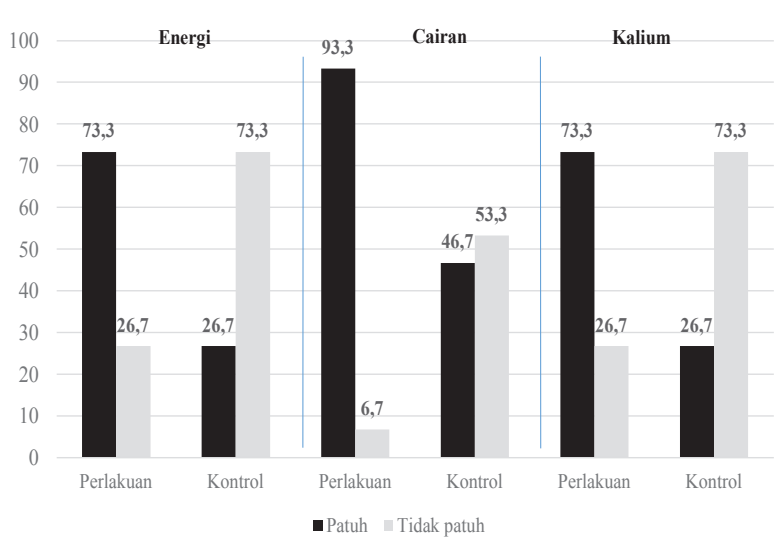

Gambar 1. Distribusi frekuensi responden berdasarkan kepatuhan dalam mengonsumsi energi, cairan, dan kalium

Tabel 1. Karakteristik responden kelompok perlakuan dan kontrol

\begin{tabular}{|c|c|c|c|c|c|}
\hline \multirow{3}{*}{ Karakteristik } & \multirow{3}{*}{ Kategori } & \multicolumn{4}{|c|}{ Kelompok } \\
\hline & & \multicolumn{2}{|c|}{ Perlakuan $(n=15)$} & \multicolumn{2}{|c|}{ Kontrol (n=15) } \\
\hline & & $\mathbf{n}$ & $\%$ & $\mathbf{n}$ & $\%$ \\
\hline \multirow[t]{2}{*}{ Usia (tahun) } & Dewasa $(<60)$ & 15 & 100 & 10 & 66,67 \\
\hline & Lansia $(\geq 60)$ & 0 & 0 & 5 & 33,3 \\
\hline \multirow[t]{2}{*}{ Jenis kelamin } & Laki-laki & 9 & 60 & 8 & 53,33 \\
\hline & Perempuan & 6 & 40 & 7 & 46,67 \\
\hline \multirow[t]{4}{*}{ IMT $\left(\mathrm{kg} / \mathrm{m}^{2}\right)$} & Underweight $(<18,5)$ & 0 & 0 & 3 & 20 \\
\hline & Baik $(18,5-22,9)$ & 12 & 80 & 7 & 46,67 \\
\hline & Overweight $(>22,9-24,9)$ & 1 & 6,67 & 4 & 26,67 \\
\hline & Obesitas $(>24,9)$ & 2 & 13,33 & 1 & 6,67 \\
\hline
\end{tabular}

IMT= indeks massa tubuh 
Tabel 2. Distribusi responden berdasarkan asupan energi, cairan, kalium pre dan post-intervensi

\begin{tabular}{|c|c|c|c|c|c|c|}
\hline \multirow{3}{*}{ Asupan } & \multirow{3}{*}{ Kelompok } & \multirow{3}{*}{ Kategori } & \multicolumn{4}{|c|}{ Waktu pengukuran } \\
\hline & & & \multicolumn{2}{|c|}{ Pre-intervensi } & \multicolumn{2}{|c|}{ Post-intervensi } \\
\hline & & & $\mathbf{n}$ & $\%$ & $\mathbf{n}$ & $\%$ \\
\hline \multirow[t]{4}{*}{ Energi } & Perlakuan & Baik & 4 & 26,67 & 11 & 73,33 \\
\hline & & Tidak baik & 11 & 73,33 & 4 & 26,67 \\
\hline & Kontrol & Baik & 5 & 33,33 & 4 & 26,67 \\
\hline & & Tidak baik & 10 & 66,67 & 11 & 73,33 \\
\hline \multirow[t]{4}{*}{ Cairan } & Perlakuan & Baik & 3 & 20 & 14 & 93,33 \\
\hline & & Tidak baik & 12 & 80 & 1 & 6,67 \\
\hline & Kontrol & Baik & 4 & 26,67 & 7 & 46,67 \\
\hline & & Tidak baik & 11 & 73,33 & 8 & 53,33 \\
\hline \multirow[t]{4}{*}{ Kalium } & Perlakuan & Baik & 4 & 26,67 & 11 & 73,33 \\
\hline & & Tidak baik & 11 & 73,33 & 4 & 26,67 \\
\hline & Kontrol & Baik & 4 & 26,67 & 4 & 26,67 \\
\hline & & Tidak baik & 11 & 73,33 & 11 & 73,33 \\
\hline
\end{tabular}

asupan baik: $80-110 \%$ kebutuhan; asupan tidak baik: $<80 \%$ atau $>110 \%$ kebutuhan

Tabel 3. Hasil uji Chi-Square efektivitas pemantauan gizi dengan SMS reminder terhadap kepatuhan diet

\begin{tabular}{|c|c|c|c|c|c|}
\hline \multirow[t]{2}{*}{ Kepatuhan diet } & \multirow[t]{2}{*}{ Kategori } & \multicolumn{2}{|c|}{$\begin{array}{c}\text { Pemantauan gizi dengan SMS } \\
\text { reminder }(\mathrm{n}, \%)\end{array}$} & \multirow[t]{2}{*}{ Total } & \multirow[t]{2}{*}{$\mathbf{p}$} \\
\hline & & Ya & Tidak & & \\
\hline \multirow[t]{2}{*}{ Energi } & Patuh & $11(73,3)$ & $4(26,7)$ & $15(50,0)$ & 0,011 \\
\hline & Tidak patuh & $4(26,7)$ & $11(73,3)$ & $15(50,0)$ & \\
\hline \multirow[t]{2}{*}{ Cairan } & Patuh & $14(93,3)$ & $7(46,7)$ & $21(70,0)$ & 0,014 \\
\hline & Tidak patuh & $1(6,7)$ & $8(53,3)$ & $9(30,0)$ & \\
\hline \multirow[t]{2}{*}{ Kalium } & Patuh & $11(73,3)$ & $4(26,7)$ & $15(50,0)$ & 0,011 \\
\hline & Tidak patuh & $4(26,7)$ & $11(73,3)$ & $15(50,0)$ & \\
\hline
\end{tabular}

Tabel 4. Hasil analisis multivariat dengan uji regresi logistik ganda

\begin{tabular}{lccc}
\hline \multicolumn{1}{c}{ Variabel } & B & Std. Error & p \\
\hline $\begin{array}{l}\text { Kepatuhan mengonsumsi } \\
\text { energi }\end{array}$ & 1,761 & 1,098 & 0,109 \\
$\begin{array}{l}\text { Kepatuhan mengonsumsi } \\
\text { cairan }\end{array}$ & 3,676 & 1,577 & 0,02 \\
$\begin{array}{l}\text { Kepatuhan mengonsumsi } \\
\text { kalium }\end{array}$ & 2,593 & 1,26 & 0,04 \\
\hline
\end{tabular}

Hasil analisis bivariat dengan uji Chi-Square dan Fisher's Exact ${ }^{*}$ ) menunjukkan bahwa pemantauan gizi dengan SMS reminder efektif mempengaruhi kepatuhan responden dalam mengonsumsi energi, cairan, dan kalium (Tabel 3).

Berdasarkan Tabel 4, hasil analisis multivariat dengan uji regresi logistik ganda menunjukkan bahwa pemantauan gizi dengan SMS reminder menjadi tidak bermakna pengaruhnya terhadap kepatuhan responden dalam mengonsumsi energi $(B=1,761 ; p=0,109)$. Sebaliknya, pemantauan gizi dengan SMS reminder menunjukkan pengaruh yang bermakna terhadap kepatuhan responden dalam mengonsumsi cairan $(B=3,676 ; p=0,02)$ dan kalium $(B=2,593 ; p=0,04)$. Berdasarkan hasil tersebut, diketahui bahwa kepatuhan dalam mengonsumsi cairan merupakan faktor yang paling dominan dipengaruhi oleh pemantauan gizi dengan SMS reminder karena memiliki $p$-value terkecil dengan $\mathrm{B}$ (kekuatan hubungan) terbesar.

\section{BAHASAN}

Seluruh responden pada kelompok perlakuan berusia dewasa sedangkan pada kelompok kontrol, jumlah responden dewasa lebih banyak (10 orang; $66,67 \%$ ) dibandingkan lansia (5 orang; 33,33\%). Pada golongan usia yang lebih tua, belum tentu tingkat 
pengetahuannya lebih tinggi apabila tidak ditunjang dengan pengalaman yang pernah dialami. Seseorang yang tidak patuh dipandang sebagai seorang yang lalai, mengalami depresi dan ansietas, dan memiliki keyakinan ego yang lebih lemah, ditandai dengan kurangnya pengendalian diri dan kurangnya penguasaan terhadap lingkungan, bukan hanya karena pengaruh tingkat usia penderita (8).

Kepatuhan diet terlihat dari perubahan persen asupan zat gizi responden sebelum dan sesudah diberikan intervensi. Responden yang patuh terlihat dari perubahan asupan yang semula tidak baik $(<80 \%$ atau $>110 \%$ kebutuhan) menjadi baik (80-110\% kebutuhan), maupun responden dengan asupan baik sejak awal hingga akhir waktu pemberian intervensi. Hasil penelitian menunjukkan kepatuhan responden dalam mengonsumsi energi, cairan, dan kalium pada kedua kelompok tidak homogen. Pada kelompok perlakuan didominasi oleh responden yang patuh sedangkan kelompok kontrol lebih didominasi oleh responden yang tidak patuh.

Pengetahuan berpengaruh pada tingkat self efficacy pada pasien hemodialisis (9). Pasien dengan hemodialisis memerlukan batasan atau aturan yang ketat mengenai jenis maupun jumlah makanan yang dikonsumsi. Salah satu contoh yaitu pasien hemodialisis yang hiperkalemia tidak diperbolehkan mengonsumsi sayur dan buah yang mengandung tinggi kalium. Oleh karena itu, pengetahuan gizi yang baik sangat berpengaruh terhadap usia harapan hidup pasien hemodialisis (10). Pada penelitian ini tidak diteliti mengenai perubahan konsumsi sayur dan buah. Namun, berdasarkan hasil wawancara, beberapa responden masih sering mengonsumsi sayur dan buah yang mengandung tinggi kalium. Studi sebelumnya menyatakan bahwa pengetahuan gizi berhubungan dengan asupan kalium pasien gagal ginjal kronik yang menjalani hemodialisis rawat jalan di RSUD Sukoharjo (11).

Pemberian SMS reminder kepada responden dalam penelitian ini selain sebagai bentuk edukasi berkesinambungan, juga merupakan bentuk pendampingan dalam pemantauan gizi. Pendampingan adalah kegiatan yang dilakukan dengan membantu seseorang menemukan apa yang diinginkan dengan menggali sumber daya apa saja yang dibutuhkan, sikap mental yang harus dibangun, dan teknik-teknik penerapan yang sesuai (12). Dengan demikian, kelompok perlakuan pada penelitian ini mengalami peningkatan kepatuhan dalam mengonsumsi energi, cairan, dan kalium akibat perlakuan yang diberikan.

Pemantauan gizi dengan SMS reminder efektif mempengaruhi kepatuhan responden dalam mengonsumsi energi, cairan, dan kalium. Intervensi pendidikan gizi melalui SMS reminder mampu meningkatkan pengetahuan dan perilaku subjek terkait penyakit dan cara pencegahannya. Peningkatan skor pengetahuan dan perilaku merupakan pengaruh dari intervensi pendidikan gizi dengan kombinasi media penyampaian pesan (SMS) (13). Pengiriman SMS kepada responden juga merupakan bentuk dukungan sosial. Kualitas interaksi antara profesional kesehatan dengan pasien merupakan bagian penting dalam menentukan derajat kepatuhan. Pasien yang menerima perhatian dari seseorang atau kelompok biasanya cenderung lebih mudah mengikuti nasihat medis dibandingkan pasien yang kurang mendapat dukungan sosial (5).

SMS reminder ini diberikan salah satunya adalah untuk mengatasi masalah malnutrisi yang banyak terjadi pada pasien hemodialisis. Asupan energi yang rendah dapat menyebabkan risiko penurunan status gizi pada pasien hemodialisis (4). Dalam penelitian ini, kepatuhan responden dalam mengonsumsi cairan merupakan faktor yang paling dominan dipengaruhi oleh pemantauan gizi dengan SMS reminder. Semakin banyak informasi yang didapatkan responden, maka tingkat kepatuhan responden terhadap pembatasan asupan cairan akan semakin baik dan sebaliknya. Kemudahan memperoleh informasi mengenai pentingnya pembatasan asupan cairan pada pasien gagal ginjal kronik, maka dapat memfasilitasi peningkatan kepatuhan dalam melakukan pembatasan asupan cairan (14). Selain kepatuhan dalam mengonsumsi energi dan cairan, kepatuhan dalam mengonsumsi kalium juga dipengaruhi oleh pemantauan gizi dengan SMS reminder. Kalium berperan dalam menurunkan tekanan darah melalui vasodilatasi pembuluh darah perifer. Konseling gizi dengan pemberian leaflet menyebabkan terjadinya perubahan perilaku untuk dapat hidup lebih baik dan lebih mengutamakan kesehatan (15).

Kelemahan penelitian ini adalah metode pemantauan gizi pasien hemodialisis dengan SMS 
reminder memiliki keterbatasan yaitu hanya dapat diterapkan terhadap pasien yang memiliki telepon genggam dan mampu baca tulis. Artinya, metode ini akan sulit diterapkan untuk pasien lanjut usia yang tergantung pada anggota keluarga yang lain atau yang tidak memiliki telepon genggam.

\section{SIMPULAN DAN SARAN}

Pemantauan gizi dengan SMS reminder efektif mempengaruhi kepatuhan responden dalam mengonsumsi energi, cairan, dan kalium. Kepatuhan dalam mengonsumsi cairan merupakan faktor yang paling dominan dipengaruhi oleh pemantauan gizi dengan SMS reminder. Pihak rumah sakit bisa menerapkan pemantauan gizi dengan SMS reminder untuk meningkatkan kepatuhan diet pasien hemodialisis, khususnya bagi pasien yang memiliki telepon genggam dan mampu baca tulis. Pasien hemodialisis yang tidak memiliki telepon genggam dan tidak mampu baca tulis seperti lansia, sebaiknya diberikan konsultasi gizi secara berkesinambungan agar pasien dapat lebih termotivasi untuk menjalankan diet yang diberikan. Perlu dilakukan penelitian lebih lanjut mengenai metode pemantauan gizi yang tepat untuk meningkatkan kepatuhan diet pasien hemodialisis yang tidak terbatas pada kepemilikan telepon genggam.

\section{UCAPAN TERIMA KASIH}

Ucapan terima kasih disampaikan kepada Kementerian Riset dan Teknologi DIKTI atas pemberian dana hibah Penelitian Dosen Pemula tahun 2016.

\section{Pernyataan konflik kepentingan}

Tidak ada konflik kepentingan dalam penelitian ini.

\section{RUJUKAN}

1. Badan Penelitian dan Pengembangan Kesehatan Kementerian Kesehatan RI. Riset kesehatan dasar tahun 2013. Jakarta: Kementerian Kesehatan RI; 2013.

2. Muttaqin A, Kumala S. Gangguan gastrointestinal: aplikasi asuhan keperawatan medical bedah. Jakarta: Salemba Pustaka; 2011.
3. Suhardjono. Buku ajar ilmu penyakit dalam jilid 2 edisi 3. Jakarta: Balai Penerbit FKUI; 2001.

4. Widiany FL. Kajian kepatuhan diet pasien hemodialisis ditinjau dari asupan zat gizi dan kenaikan berat badan interdialisis. Medika Respati Suplemen 2017;12:137-42.

5. Niven. Psikologi kesehatan. Jakarta: EGC; 2002.

6. Lemeshow S, Hosmer JrDW, Klar J, Lwanga SK. Besar sampel dalam penelitian kesehatan (alih bahasa). Yogyakarta: Gadjah Mada University Press; 1997.

7. Rachmawati TY, Syauqy A. Hubungan pengetahuan gizi dengan asupan energi, protein, phosphor dan kalium pasien penyakit ginjal kronik dengan hemodialisis rutin di RSUD Tugurejo Semarang. Journal of Nutrition College 2014;3(1):271-7. doi: 10.14710/jnc.v3i1.4607

8. Kamaluddin R, Rahayu E. Analisis faktor-faktor yang mempengaruhi kepatuhan asupan cairan pada pasien gagal ginjal kronik dengan hemodialisis di RSUD Prof. Dr. Margono Soekarjo Purwokerto. Jurnal Keperawatan Soedirman 2009;4(1):20-31. doi: 10.20884/1. jks.2009.4.1.218

9. Rahimi F, Gharib A, Beyramijam M, Naseri O. Effect of self-care education on self efficacy in patients undergoing hemodialysis. Life Sci Journal 2014;11(1):136-40.

10. Zuyana L, Adriani M. Perbedaan asupan makan dan status gizi antara pasien hemodialisis adekuat dan inadekuat penyakit ginjal kronik. Media Gizi Indonesia 2013;9(1):139.

11. Nastiti F. Hubungan tingkat pendidikan dan pengetahuan gizi terhadap asupan kalium pada pasien gagal ginjal kronik yang menjalani hemodialisa rawat jalan di RSUD Sukoharjo [Skripsi]. Surakarta: Program Studi Ilmu Gizi Universitas Muhammadiyah Surakarta; 2015.

12. Jerusalem MA. Peningkatan keterampilan bisnis mahasiswa dengan teknik coaching. Prosiding Seminar Nasional PTBB; 2011; Yogyakarta.

13. Kusfriyadi MK, Hadi H, Fuad A. Pendidikan gizi dan pesan gizi melalui short message service terhadap pengetahuan, perilaku, dan kepatuhan ibu hamil minum tablet besi. Jurnal Gizi Klinik Indonesia 2012;9(2):87-96. doi: 10.22146/ ijen. 15385

14. Mardjun F. Faktor yang berhubungan dengan kepatuhan pembatasan asupan cairan pada pasien gagal ginjal kronik di ruang hemodialisa RSUD Prof. Dr. H. Aloei Saboe Kota Gorontalo [Skripsi]. Gorontalo: Universitas Negeri Gorontalo; 2014.

15. Suwarni, Asdie HAH, Astuti H. Konseling gizi dan pengaruhnya terhadap asupan zat gizi dan tekanan darah pada pasien hipertensi rawat jalan di Rumah Sakit Umum Daerah Provinsi Sulawesi Tenggara. Jurnal Gizi Klinik Indonesia 2009;6(1):21-8. doi: 10.22146/ijen.17684 